\title{
Intercultural Communication: Business negotiations in Kazakhstan
}

\author{
Diana Akizhanova \\ L.N. Gumilyov Eurasian National University, 5 Munaitpassov Str., Astana 010000, Republic of Kazakhstan \\ diana.akizhanova@bk.ru
}

\begin{abstract}
The paper sets forth the need for an increase in research in intercultural business communication in Kazakhstan, particularly business negotiations. The Republic of Kazakhstan is quite a young country which is about 20 years since it has got its independence. It is one of the former USSR countries. Kazakhstan is a multicultural country; there are more than 140 various nationalities that live in peace and agreement. When we speak of various nationalities we mean different cultures, different mentalities, different languages as well as different norms and standards of communication. Hence, living in such a variety of cultures in order to communicate and interact successfully, people improve their intercultural communication skills, literacy and competence. Along with the growth of economics and commerce in Kazakhstan the level of intercultural communication competence increases also. Thus, we can state that people living in a multilingual country obtain high level of intercultural communication skills, as well as intercultural literacy and competence. This is particularly critical for business dealers during their business trips, negotiations, signing agreements and contracts, etc. There are many cases in the world when misunderstandings due to lack of knowledge in the culture of business partners or communicative (cultural) barriers prevent from signing an agreement or even lead to failure of the business. And that is why intercultural communication is such an important and critical subject to study in the business sector nowadays. The paper tries to describe some specific features of Kazakhstani people in business negotiations, provides some cultural values of the Kazakh people and some cases of cultural misunderstandings that resulted in failure of business negotiation.

Index Terms - linguistics, intercultural communication, business communication, negotiations, Kazakhstan.
\end{abstract}

\section{Introduction}

The Republic of Kazakhstan is quite a new country which is about 20 years. Besides its young age, it is a multicultural country where more than 140 nationalities live and speak different languages. Speaking different languages can imply different cultures, different mentalities and different views of the world. Nowadays, in the period of globalization and standardization, many countries communicate and interact with each other. This was one of the grounds for the establishment of intercultural communication as (an interdisciplinary) science.

More and more countries get involved into the global village for the reasons of economic, political, commercial, educational and other issues. But the main purpose of all of them is communication for business. The word combination 'global village' was first used by Canadian philosopher of communication theory Herbert Marshall McLuhan in his book The Gutenberg Galaxy: The Making of Typographic Man,
$1962^{1}$.

The first step in learning to communicate with people from other cultures is to become aware of what culture means. Our awareness of intercultural differences is both useful and necessary in today's world of business. "In intercultural communication ignorance leads to uncertainty, and uncertainty, at times, to fear, passivity or errors, and as a consequence loss of money" says C. Wachsmuth in one of the lectures on negotiations ${ }^{2}$.

In order the communication was successful it is very important to start it in a right way, i.e. it is very critical for business persons not only to know the main rules and strategies of negotiations but not to forget about intercultural aspects of that negotiation.

\section{Negotiations in Kazakhstan}

First of all, let us define what the word negotiation means.

According to the Compact Oxford English Dictionary ${ }^{3}$ to negotiate means: "Try to reach an agreement or compromise by discussion." According to Iké: "To begin with, two elements must normally be present for the negotiation to take place: There must be both common interests and issues of conflict; if there are no common interests there is nothing to negotiate about and without conflicting issues nothing to negotiate about".

Negotiation is one of the important forms of business communication and intercultural cooperation in politics, business, and cultural cooperation. In modern times, they are a major tool for solving many current problem ${ }^{4}$.

The form of negotiations is chosen depending on the purpose, nature, number of participants, the level of representation and other factors. Historically, the first form of negotiation were congresses (from Lat. Congresses - an appointment, meeting) ${ }^{5}$. Speaking of diplomacy, it made history of Vienna congress (1814 - 1815) and Congress of Aix-la-Chapelle (Aachen) (1818), where documents approving the rules of diplomatic missions were adopted. After the Berlin Congress (1878) on resolving the Russian-Turkish relations such form of negotiation in diplomacy was not used any more.

But it is not enough just to know the strategy and right ways of communicating and negotiating, as we mean intercultural communication we should not forget about language and cultural barriers that can arise between the representatives of two parties. In 1996 Financial Times stated that $49 \%$ companies exporting goods faced language and 
cultural barriers; $12 \%$ companies ceased to exist because of these barriers; and only $13 \%$ companies had at least some language and cultural training ${ }^{6}$. It is obvious how many agreements and contracts fail to be signed just because of such 'background abysses', we call it background because for the moment of negotiation business people do not pay attention to such things as they get prepared for the business discussion itself, but few of them obtain some cultural knowledge of the target company before going to the meeting. These are minor but critical issues.

Nowadays, in terms of intercultural communication and interrelation, Kazakhstan is making a lot of agreements and collaborations with other countries. According to the Agency of Statistics of the Republic of Kazakhstan the foreign trade turnover of the country in the first half-year of 2012 was about $\$ 66688$.1, which $\$ 46755.3$ is for export and $\$ 19932.8$ is for import. Comparing with the first half-year of 2011 it has increased in $114.2 \%$, i.e. $110.8 \%$ in export and $123.2 \%$ in import.

The basis of this research was taken from the classification of cultures by Fons Trompenaars. He regulates the organizational culture of the company not only in technology and markets, but also on the national cultural preferences of managers and employees of the organization. To revise, he divided 5 types of cultural dimensions that can be considered as analogues to Hofstede's indexes: Universalism vs. Particularism; Individualism vs. Collectivism; Neutral vs. Affective Relationships; Specific vs. Diffuse Relationships; Achievement vs. Ascription.

According to this classification Kazakh culture can be described as universalistic (rules or laws that can be applied to everyone; agreements and contracts are used as the basis for doing business); collectivistic (frequent use of "we"; people ideally achieve objectives in groups and assume joint responsibility, avoid taking personal responsibility); affective (nonverbal and verbal display of thoughts and feelings; transparency and expressiveness in release of tensions; easy flow of emotions); and diffuse (no clear distinction between work and private life); and relates to achievement relationships (awarding status based upon accomplishments).

These dimensions are very important, especially when Kazakhstani dealers do business with representatives of other cultural dimensions. For example, advertising that focuses on individual success, independence and stressing the word "I" would be received negatively in Kazakhstan where teamwork is considered a positive quality. As well as rebelliousness or lack of respect for authority should always be avoided in family orientated or hierarchical societies ${ }^{7}$. Another good example is when General Motors introduced a car Chevy NOVA to the Mexican market, but the specialists did not think about the fact that no va in Spanish means "does not go". This was the reason of the business failure.

"Culture is a like dropping an Alka-Seltzer into a glass you don't see it, but somehow it does something" says Hans Magnus Enzensberger ${ }^{8}$. There are a lot of points that people do not pay attention to, but which can be critical for business negotiation. In order to see the differences of the Kazakhstani intercultural communication let us first define cultural values of the Kazakh people:

Hospitality. The Kazakh nation educates its generation to respect its traditions and customs. Nomadic culture and hospitality has always been an important part of the Kazakh culture. There are a lot of sayings and proverbs teaching people to display generosity and hospitality. For example the proverb "asyna toighyzbasan da aq niyetine toigyz (if you can't treat [a guest] with meals, at least treat with your genuine intention/honesty)" completely describes the attitude of the Kazakh people towards the hospitality. In earlier times it was considered that a guest chose the best house to stay in and it was an honor for the owner of the house whose house was often visited by guests. Sometimes people said that not welcoming and inviting guests was equal to transgression. Probably this is the reason why the Kazakh people used to eat from a big round plate that is usually put in the middle of round table. Here we can see the round shape of the table and plate meaning that everybody even unexpected guests could have meal together with the owner of the house and that space at the table can be found for everybody. Welcoming behaviour and hospitality are common in both social and business Kazakh spheres.

Example, Бір заманда орыс пен қазақ көрші тұрыпты. Орыс қазақша, қазақ орысша білмепті. Бір күні қонақ жай қазақ орысты үйіне қонаққа шақырыпты. Орыс қазақтың үйіне келіп дастарханда ештеңе жемей отырыпты. Сосын қазақ "ұйалмай жей бер" дегенді қалай айтарын білмей, орысқа "ешь, ешь как тебе не стыдно" депті. Орыс одан сайын ештеңе жемей бір орында отыра беріпті. Сосын қазақ ойлапты "мүмкін бұған қой сойып беру керек шығар деп". Сосын оны қалай айтарын білмей орысқа "я тебя как баран зарежу" депті. Орыс орнынан тура салып қашып бара жатса. "Ары-бері өткенде келіп тұр" дегенді қалай айтарын білмей , қашып бара жатқан орысқа "туда-сюда пройдешь, все равно поймаю"депті

Tradition. Traditions and customs of the Kazakh nation have been transferred from one generation to another through stories told by traditional Kazakh aksakals (old people, especially men). For many years the Kazakh nation was under the impact of Soviet reign but the Kazakhs managed to save its traditional culture and customs. Upon achievement of its independence Kazakhstan has been reviving its forgotten traditions and now many feasts are celebrated and considered as national holidays.

Respect. The Kazakh people used to teach their children to respect elders. Respect of elders and of the spiritual freedom is one of the most important and principal values that a person should obtain according to the Kazakh conception. There a lot of stories teaching people to respect others. In the Kazakh language we can see words such as dat, shydamdylyq, sabyr, sabyrlylyq, tozim, tozimdiliq, degbir, etc. All of them are translated as tolerance, patience, but each of them has a specific feature and all of them cannot be used in the same context. All these words show the attitude of the Kazakh 
people to the tolerance as a value. Moreover, trial of a person for tolerance can be seen from a religious holiday Sawm (Ramadan). Sawm means to abstain from eating, drinking (including water), smoking, having sexual intercourse from dawn to sunset and this cleaning procedure lasts for a month. The meaning of such holiday is to teach people be tolerant and respectful to others, especially to empathize with those less fortunate ones who do not always have food and drink readily available.

Collectivism. As we have already said above collectivism takes place when people ideally achieve objectives in groups and assume joint responsibility, avoid taking personal responsibility. It is considered not ethical and accepted negatively when a person says his/her own achievements boastfully and emphasizes his/her progress. The concept "us" in the traditional Kazakh society has always been more significant than that of "me".

Freedom. Freedom can be seen from the nomadic style of living of ancient Kazakhs. It is important value of the society being formed in Kazakhstan. This must provide everyone with the possibility of creative self-realization. Nomads have always been famous for a freedom-loving spirit. The feeling of freedom resulted in special attitude to the environment, developed awareness and profound interest in the world.

Patriotism: The formation of civil society institutions is impossible without the development of a patriotism shared by the entire Kazakhstan, and with deep roots in the culture, psychology, and historical past of the Kazakhs. In a traditional Kazakh society such values as love of the Motherland (atameken), its veneration and care have also been strong.

Additionally, we can observe when foreign people arrive in Kazakhstan, not only in business sphere but in ordinary life also, the Kazakh people present gifts to the guests. This gesture sometimes is encouraged and accepted pleasantly. But sometimes it can be taken negatively, for example for German businessmen exchanging presents is not acceptable and considered as flagrant violation. This can be explained in the following way: German businessmen are generally not prepared to accept gifts, especially during the first contact, and even from strangers. Most often, these gifts were the basis for the conclusions of interested motives of the partners' behavior. The role of the gifts to representatives of Asian culture has a completely different meaning. According to their views do business primarily be based on interpersonal relationships. Therefore, long-term relationship in the future should start by building strong personal relationships. For this first partner thoroughly tested for reliability and value for value ideas. As soon as it becomes clear that the partners for each other and have long-term interests, relationships are originally installed through the continuous exchange of signals and a sort of "investment" (gifts, souvenirs). According to the Asian model of the behavior of the establishment of personal relationships in business transactions is considered as a necessary condition for them. To the success of business contacts in the Asian model, along with personal relationships necessary to establish a system of mutual obligations (you - me, me - you). It is important as a prerequisite for every subsequent stage of communication. A system of relations should be established at the very beginning of the business relationship. Therefore it can not be the last link of communication, as in the West. In the West, trying to avoid anything that might look like a bribe. Invitations and gifts are considered undesirable influence or even an attempt at bribery. The Western model of conduct is based on a strict and categorical ethics that does not allow any exceptions.

Another important point in business negotiation are kinesic, in particular, mimic lexical gaps. One of them is smile. In different cultures, a smile can have, depending on the existing rules of etiquette, different iconography and values. Many Kazakhstani people do not understand western people smiling 'for no reason'. In the Western world, in general, and in the English language, in particular, smile is a sign of culture..., it is a tradition, custom: stretch lips into position to show that you have no aggressive intentions, you are not going to rob or kill ${ }^{9}$. Kazakh culture understands smile as not necessary, not serious. For example, S. Ter-Minassova in her book Language and Intercultural Communication provides a good example of American smile: the smile of Hillary Clinton on the funerals of Princess Diana ${ }^{9}$. It is unacceptable for Kazakh culture to smile on funerals. However, the difference lies in American slogan 'Keep on smiling!' - for Americans it is very important to be smiling even in the difficult and painful moments of life. On the contrary, Asian people think that the higher the position of a person is, the more serious he/she should be. It will be comic in Asian countries to smile during business negotiations, as people can decide that the person smiling is not serious and is not worth dealing with.

One of the best ways to make a favorable first impression - and to get ahead socially or in business - is to remember people's names. "A person's name is to him or her is the sweetest and most important sound in any language" says Dale Carnegie. "Most people do not remember the name for the reason they do not want to waste time and energy trying to concentrate, memorize, indelibly capture these names in his memory... However, they are hardly more busier than Franklin Roosevelt... F. Roosevelt knew that one of the easiest, most user friendly and most effective ways to win the favor of others - is to remember their names and instill sense of his own significance"10.

"In international negotiations, communication style, expectation, issue ranking and goals will change according to the negotiators' countries of origin. If applied properly, the understanding of cultural dimensions should increase success in negotiations and reduce frustration and conflicts" ${ }^{\prime 1}$. Another big problem that usually arise at negotiations is salutation. It is known that remembering person's name and addressing him/her in the right way can be a key for successful business. There was a case when based on the agreement of General Electric with Kazakhstan Locomotive Building Plant, a Kazakh businessman addressed to American partner, John Smith, by calling him 'Mr. John'. This is the most widespread mistake that usually appears in business 
communication. The problem is that in Kazakh language people usually address other by "Mr./Mrs. + Name". Surname is usually not used. But due to long history of being under the reign in the USSR and under the impact of Russian culture, it is usual to meet a person addressing by Russian way as "Name +Patronymic". However, not many people know that in American (English) style it is correct to address a person by "Mr./Mrs+Last Name". Moreover addressing people just saying their last names can be considered as offensive, however addressing by just names can express the attitude of the addresser as a wish to become in friendly relationships with the addressee.

In Kazakh, as in most languages of the world, pronoun as addressing to the second person has two forms siz (formal) and sen (informal), and, in some languages only one pronoun: in English, Caucasian, etc. However, in Kazakh (sen and siz in singular, and sender and sizder in plural respectively), the choice of form has certain shades of human relationships. Kazakh "sen" may offend, "Magan sen deme!" (Don’t say 'you' to me!) in the meaning that one should respect another and address in formal form with the pronoun 'siz'. Hence, this aspect should be also taken into consideration during negotiations.

There are many cases and examples of intercultural misunderstanding and business failures resulting from them. However, it is critical to note the mild distinction between words misunderstanding and misinterpreting in the aspect of intercultural communication. As in the case of misunderstanding the problem can occur due to the lack of knowledge in cultural differences and values. However, in the case of misinterpreting the problem can be because of incorrect use of the words in translating. "To a touchy negotiator, to say that he or she "misunderstands" may imply that he or she is dim-witted. To say that same negotiator "misinterprets" a concept, by contrast, allows the negotiator a way to save face since all interpretations are arguable... The translation, however, which the Mexican-based Englishspeaking employees saw no reason to avoid, used the term "embarazada" to mean "embarrassed." This provided much amusement to the Mexican market, as "embarazada" means "pregnant" in Mexican Spanish ${ }^{12}$.

\section{Conclusions}

Kazakhstan is very rich in traditions and customs that bear principal value to the Kazakh culture. That is why in order to have successful negotiation and a business deal it is critical to know at least the most wide spread specifics of the Kazakh culture.

In the conclusion, we would like to remember the words of Roger E. Axtel, vice president of The Parker Pen Company "If offered, you should eat the roast gorilla hand" or the most popular proverb for the last time that directly describes cultural differences: "when in Rome do as Romans do". Owing to the difference cultural norms and standards there are no definite communication strategies set for all business negotiations nowadays. So, in order to get a successful negotiation it is important not only to learn but also to understand the culture of the addressee, as language and cultural barriers are not the only gate for a jackpot.

\section{Acknowledgments}

This work was supported in part under the Grant of the Ministry of Science and Education of the Republic of Kazakhstan.

\section{References}

[1] www.wikipedia.org

[2] C. Wachsmuth, Managed negotiations or 'Game by European rules' (in Russian), Available at: www.it-study.by

[3] Compact Oxford English Dictionary (2009)

[4] M. M. Lebedeva, Editor, Vam predstoyat peregovory, Ekonomika, Moscow (2006) (in Russian)

[5] V. I. Trukhacheva, I. N. Lyakisheva, K. Yu. Mikhailova, Editors, Mezhdunarodnye delovye pregovory (International Business Negotiations), (2006) (in Russian)

[6] Breaking the language barrier, Financial Times, October 10, (1996)

[7] Cross-cultural advertising. www.kwintessential.co.uk

[8] Cross-cultural advertising. www.kwintessential.co.uk

[9] S.Ter-Minassova, Editor, Language and Intercultural Communication, 190 (2000)

[10] D. Carnegie, How to Win Friends and Influence People, 114 (1994)

[11] Michelle Lebaron, Negotiation styles, Available at: www. beyondintractability.org

[12] David A. Victor, Cross-cultural / international communication in Reference for Business, $2^{\text {nd }}$ ed. (2012). Available at: www.refrenceforbusiness.com 